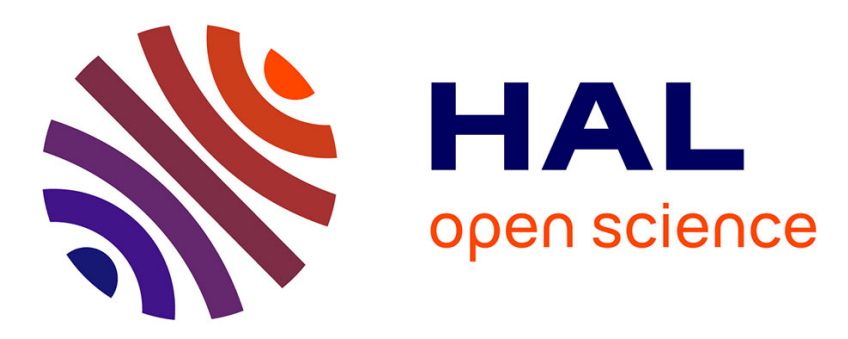

\title{
Improving communication about viral hepatitis in Africa.
}

Yusuke Shimakawa, Dolorès Pourette, Louis Bainilago, Catherine Enel, Roger Sombié, Ramanampamonjy Rado, Maud Lemoine, Tamara Giles-Vernick

\section{- To cite this version:}

Yusuke Shimakawa, Dolorès Pourette, Louis Bainilago, Catherine Enel, Roger Sombié, et al.. Improving communication about viral hepatitis in Africa.. The Lancet Infectious Diseases, 2017, 17 (7), pp.688-689. 10.1016/S1473-3099(17)30339-0 . pasteur-01567827

\section{HAL Id: pasteur-01567827}

\section{https://hal-pasteur.archives-ouvertes.fr/pasteur-01567827}

Submitted on 24 Jul 2017

HAL is a multi-disciplinary open access archive for the deposit and dissemination of scientific research documents, whether they are published or not. The documents may come from teaching and research institutions in France or abroad, or from public or private research centers.
L'archive ouverte pluridisciplinaire HAL, est destinée au dépôt et à la diffusion de documents scientifiques de niveau recherche, publiés ou non, émanant des établissements d'enseignement et de recherche français ou étrangers, des laboratoires publics ou privés.

\section{(1) (1) $\$$}

Distributed under a Creative Commons Attribution - NonCommercial - NoDerivatives $\mid 4.0$ 
Shimakawa Y, Pourette D, Bainilago L, et al. Improving communication about viral hepatitis in Africa. Lancet Infect Dis. 2017; 17(7) : 688-689.

http://www.thelancet.com/journals/laninf/article/PIIS1473-3099(17)30339-0/abstract

\section{Title}

Improving communication about viral hepatitis in Africa

\section{Authors}

Yusuke Shimakawa, $\mathrm{PhD},{ }^{1}$ Dolorès Pourette, $\mathrm{PhD},{ }^{2,3}$ Louis Bainilago, $\mathrm{PhD},{ }^{4}$ Catherine Enel, $\mathrm{PhD},{ }^{2}$ Roger Sombié, MD, ${ }^{5}$ Ramanampamonjy Rado, PhD, ${ }^{6}$ Maud Lemoine, $\mathrm{PhD},{ }^{7}$ Tamara Giles-Vernick, $\mathrm{PhD}^{1}$

\section{Affiliations}

${ }^{1}$ Unité d'Épidémiologie des Maladies Émergentes, Institut Pasteur, Paris, 25-28 rue du Dr Roux, 75015, Paris, France

${ }^{2}$ UMR 196 CEPED (IRD-Université Paris Descartes-INSERM), Paris, France

${ }^{3}$ Université Catholique de Madagascar, Antananarivo, Madagascar

${ }^{4}$ Département d'Anthropologie, Université de Bangui, Bangui, Central African Republic

5 Département d'Hépato-gastroentérologie, Centre Hospitalier Universitaire Yalgado Ouédraogo, Ouagadougou, Burkina Faso

${ }^{6}$ Unité d'Hépato-Gastro-Entérologie, Hôpital Joseph Raseta Befelatanana, Antananarivo, Madagascar

${ }^{7}$ Department of Surgery and Cancer, Liver Unit, Imperial College London, UK 


\section{Corresponding Authors}

Dr Yusuke Shimakawa

Unité d'Épidémiologie des Maladies Émergentes, Institut Pasteur, Paris, 25-28 rue du Dr Roux, 75015, Paris, France

Email : $\quad$ yusuke.shimakawa@pasteur.fr

Phone : $\quad+33(0) 140613887$

Fax : $\quad+33(0) 145688876$

Dr Tamara Giles-Vernick

Unité d'Épidémiologie des Maladies Émergentes, Institut Pasteur, Paris, 25-28 rue du Dr Roux, 75015, Paris, France

Email : $\quad$ tamara.giles-vernick@ pasteur.fr

Phone : $\quad+33(0) 140613982$

Fax : $\quad+33(0) 145688876$

\section{Keywords}

Hepatitis B; Africa; communication; knowledge; anthropology; elimination 


\section{Main Text}

Viral hepatitis is the seventh leading cause of death worldwide. ${ }^{1}$ By 2030 , WHO's elimination strategy $^{2}$ seeks to reduce mortality from chronic infection with hepatitis $\mathrm{B}$ and $\mathrm{C}$ viruses by $65 \%$. To achieve this goal, it is essential to scale up antiviral treatment programmes in lowincome and middle-income countries, where most deaths due to hepatitis occur. These programmes must identify, engage and retain infected populations. Yet only with a genuine understanding of viral hepatitis can people living with these infections fully commit to a treatment program. WHO published new guidelines for testing for hepatitis B and hepatitis C viruses in February $2017 ;^{3}$ however, the guidelines make little mention of communicating with these populations about chronic viral hepatitis. Our anthropological research investigating local understandings of hepatitis B in sub-Saharan Africa (The Gambia, ${ }^{4}$ Côte d'Ivoire, ${ }^{5,6}$ Burkina Faso, ${ }^{7,8}$ Central African Republic ${ }^{7}$ and Madagascar ${ }^{9}$ ) highlighted communication challenges between health-care workers and local populations.

Knowledge of hepatitis is slim to non-existent in sub-Saharan African populations, although the prevalence of chronic hepatitis B virus infection exceeds $8 \%$ in that region. ${ }^{4}$ Less than $1 \%$ of The Gambia's general population has heard of hepatitis B, although most were familiar with HIV/AIDS and malaria. ${ }^{4}$ Our findings in Burkina Faso, Côte d'Ivoire and Madagascar suggested a similar lack of recognition of hepatitis B in these countries. ${ }^{5,6,8}$ Nevertheless, a small, knowledgeable lay public in these three countries use the illness category hepatitis, which they associate with wide-ranging causes and symptoms. ${ }^{7}$

That the African lay public is unfamiliar with hepatitis B might be related to the complex natural history of chronic infection. ${ }^{10}$ Most infected people remain asymptomatic for decades, without recognising their chronic carriage unless they undergo blood donation screening or develop decompensated cirrhosis or hepatocellular carcinoma. ${ }^{8,11}$ 
Nevertheless, some sub-Saharan African populations appear to recognize and name symptoms associated with end-stage liver disease. In the Central African Republic, Bangui people use the terms lé ti mafuta (palm oil eyes) or fièvre jaune (yellow fever) to evoke jaundice, whereas Djula and Mooré speakers in Burkina Faso and Mandinka speakers in The Gambia use diagnostic categories that describe ascites symptoms: founoubana (swelling sickness), kapouga (mature millet panicle) and konofa jankaroo (full stomach sickness). ${ }^{7,8}$ In Madagascar, some also speak of angorigosy or tazo-vony (big fever), suggesting acute hepatitis symptoms.

Although these local terms capture vividly the signs and symptoms of liver disease, they might have alternative biosocial causes, most notably sorcery, that shape patients' healthseeking practices. ${ }^{7}$ Gambian and Burkinabé illness categories referring to abdominal swelling frequently identify sorcery as a cause, requiring traditional healers' interventions. Redressing social transgressions through incantations and other ritual practice, healers also use various herbal and animal substances with emetic and laxative effects to reduce abdominal swelling. These treatments might not only delay access to medical care but also worsen a patient's prognosis.

Finally, African health workers struggle to explain hepatitis B to those who are chronically infected and must navigate lay incomprehension, complex local illness categories, and their own, often insufficient, biomedical knowledge. African health workers frequently rely on other disease categories to explain this illness. Some evoke local terms for severe malaria eg, sumaya (cold fever) in Djula language, Burkina Faso - or alternatively, describe hepatitis B as "like HIV", suggesting erroneously that both viruses have identical transmission modes, diagnostic tests; and treatments. ${ }^{6,8}$ In regions with a low prevalence of hepatitis B infection (Europe, North America), transmission of both hepatitis B virus and HIV occurs mainly through sexual intercourse or use of intravenous drugs. By contrast, in sub-Saharan Africa, 
hepatitis B virus was mainly transmitted horizontally during childhood before the introduction of hepatitis B vaccine. ${ }^{12}$ The message that hepatitis B is "like HIV" confuses patients and families and increases stigmatisation.

Considerable challenges hamper effective communication between health workers and people with chronic hepatitis. A first step in addressing the burden of chronic hepatitis in subSaharan Africa would be to improve training of health workers in understanding viral hepatitis. A second step would be to create more effective, meaningful communication strategies for health workers to use with patients. Development of these measures through anthropological research will set critical foundations for treatment scale-up in low-income and middle-income countries, which can contribute to the global elimination of viral hepatitis. We declare no competing interests.

\section{Acknowledgements}

We thank the Agence Nationale de la Recherche sur le SIDA et les Hépatites (ANRS 12232, 12258 and 12287), the European Commission (PROLIFICA study), and the Total Foundation (NéoVac Study) for their generous funding.

\section{References}

1 Stanaway JD, Flaxman AD, Naghavi M, et al. The global burden of viral hepatitis from 1990 to 2013: findings from the Global Burden of Disease Study 2013. Lancet 2016; 388: $1081-8$.

2 WHO. Global Health Sector Strategy on Viral Hepatitis 2016-2021. Geneva, Switzerland, 2016.

3 WHO. Guidelines on hepatitis B and C testing. Geneva, Switzerland, 2017. 
4 Lemoine M, Shimakawa Y, Njie R, et al. Acceptability and feasibility of a screen-andtreat programme for hepatitis B virus infection in The Gambia: the Prevention of Liver Fibrosis and Cancer in Africa (PROLIFICA) study. Lancet Glob Heal 2016; 4: e559-67. 5 Pourette D, Enel C. Representations and disease experience of hepatitis B by SubSaharan patients in Ivory Coast and France. Sante Publique (Paris) 2014; 26: 869-78.

6 Enel C, Desgrées du Loû A, N’Dri Yoman T, Danel C, Larmarange J. Viral hepatitis B and C in Ivory Coast: stepping up the fight, a pressing need. J Afr Hépatol Gastroentérol 2015; 9: 94-8.

7 Giles-Vernick T, Traoré A, Bainilago L. Incertitude, hepatitis B and infant vaccination in West and Central Africa. Med Anthropol Q 2016; 30: 203-21.

8 Giles-Vernick T, Hejoaka F, Sanou A, Shimakawa Y, Bamba I, Traore A. Barriers to Linkage to Care for Hepatitis B Virus Infection: A Qualitative Analysis in Burkina Faso, West Africa. Am J Trop Med Hyg 2016; 95: 1368-75.

9 Institut de Recherche pour le Développement (IRD) Madagascar. NéoVac. 2015. http://www.madagascar.ird.fr/les-activites/la-recherche3/madagascar/dynamiques-depopulation/neovac (accessed March 4, 2017).

10 Shimakawa Y, Lemoine M, Njai HF, et al. Natural history of chronic HBV infection in West Africa: a longitudinal population-based study from The Gambia. Gut 2016; 65: 200716.

11 Shimakawa Y, Takao Y, Anderson ST, et al. The prevalence and burden of symptoms in patients with chronic liver diseases in The Gambia, West Africa. Palliat Med 2015; 29: $184-5$.

12 Whittle HC, Inskip H, Bradley AK, et al. The Pattern of Childhood Hepatitis B Infection in Two Gambian Villages. J Infect Dis 1990; 161: 1112-5. 
